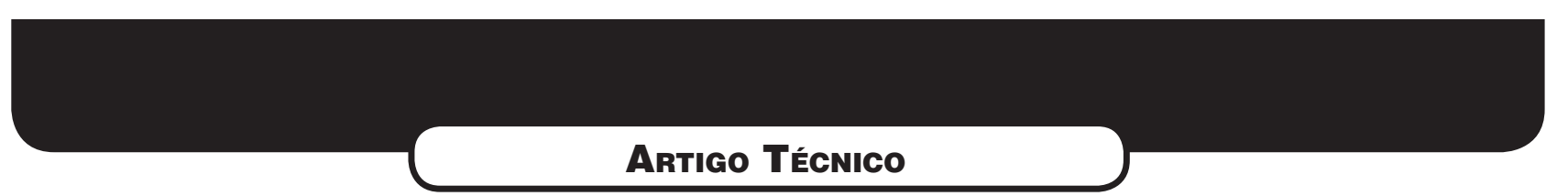

\title{
DESEMPENHO OPERACIONAL E AMBIENTAL DE UNIDADES DE RECICLAGEM E DISPOSIÇÃO FINAL DE RESÍDUOS SÓLIDOS DOMÉSTICOS FINANCIADAS PELO ICMS ECOLÓGICO de Minas Gerais'
}

\author{
OPERATIONAL AND ENVIRONMENTAL PERFORMANCE OF SANITARY LANDFILLS \\ AND RECYCLING FACILITIES SUPPORTED BY THE ECOLOGICAL ICMS IN \\ Minas Gerais State, Brazil
}

\begin{abstract}
JoSÉ FRANCISCO DO PRADO FILHO
Ecólogo (UNESP - Rio Claro-SP). Doutor em Ciências da Engenharia Ambiental (EESC -Universidade de São Paulo). Professor da Escola de Minas, Departamento de Engenharia de Produção, Universidade Federal de Ouro Preto

FREDERICO GARCIA SOBREIRA

Geólogo (UFRJ). Doutor em Geologia Ambiental (Universidade de Lisboa), Professor da Escola de Minas, Departamento de Geologia, Universidade Federal de Ouro Preto

Recebido: 20/09/05 Aceito: 18/01/07
\end{abstract}

\section{RESUMO}

Este estudo avalia sistemas de reciclagem e de disposição de resíduos sólidos domésticos que possuem incentivos fiscais definidos pela Lei Estadual no 13.803/2000 de Minas Gerais. A pesquisa foi desenvolvida por análise de documentação de licenciamento ambiental de aterros sanitários e usinas de reciclagem e compostagem de resíduos financiados pela referida Lei e por visitas às unidades sanitárias, sendo usados os instrumentos metodológicos da agência ambiental do Estado de São Paulo (CETESB) que avaliam as condições de instalação e operação desses tipos de empreendimentos. Do estudo, constatou-se que o incentivo de Minas Gerais, definido pela Lei do ICMS Ecológico, traz importantes benefícios ambientais aos municípios, embora ainda seja reduzido o número dos contemplados por esse fomento à gestão dos resíduos sólidos urbanos. Conclui-se, também, que algumas das unidades estudadas apresentam problemas de natureza ambiental e operacional.

PALAVRAS-CHAVE: Resíduos sólidos, usinas de reciclagem de resíduos, aterros sanitários, Índice de Qualidade de Aterros - IQR, Índice de Qualidade de Unidades de Compostagem - IQC.

\section{INTRODUÇÃO}

Fatores como crescimento demográfico, melhora do nível socioeconômico da população, desenvolvimento de novos hábitos e intensificação do consumo, além de provocar modificações nas características dos resíduos sólidos gerados, acabam por trazer dificuldades técnicas

\begin{abstract}
This paper reports a qualitative assessment made at the sanitary landfill, recycling centers and composting units sponsored by the State Law No 13.803/2000, Minas Gerais, Brazil. The analyses of all the documentation used for the environmental licensing process as well as field trips to sanitary landfills and domestic recycle/composting unities were performed. The IQC and IQR indexes from the São Paulo State Environmental Agency (CETESB) were used as quality assessment tools. It is concluded that this State Law (Ecological ICMS Law) has been promoting substantial environmental benefits to the local communities, despite it is still small the number of cities which have been attended by this regulation for solid waste management. On the other hand, it can be noticed that some operational and environmental issues remain to be addressed in the visited facilities.
\end{abstract}

KEYWORDS: Solid waste, recycling facilities, sanitary landfill, Landfill Quality Index, Recycling Facilities Index.

\footnotetext{
${ }^{1} \mathrm{O}$ presente estudo teve o suporte financeiro da Fundação de Amparo à Pesquisa do Estado de Minas Gerais - FAPEMIG.
} 
Imposto sobre Operaçôes Relativas à Circulação de Mercadorias e sobre Prestações de Serviços de Transporte Interestadual e Intermunicipal e de Comunicação (ICMS), permitindo que eles se beneficiem desses recursos, por meio da apresentação de projetos em várias áreas, inclusive meio ambiente $\mathrm{e}$ saneamento.

Com essa Lei, o repasse de parte dos $25 \%$ do total arrecadado pelo Estado e pertencente aos municípios, como definido pelo inciso II do parágrafo único do artigo 158 da Constituição Federal, não leva em conta a arrecadação de cada um deles, mas os investimentos realizados pelas prefeituras em saúde, educação, meio ambiente e saneamento, agricultura e preservação do patrimônio histórico e cultural. Por conta disso, a referida Lei passou a ser conhecida como Lei Robin Hood e Lei do ICMS Ecológico, pois uma fatia maior da receita arrecadada pelo Estado pode ser destinada a municípios pobres, desde que estes apresentem projetos e propostas nas áreas especificadas acima. Segundo a Fundação Estadual do Meio Ambiente-FEAM (1998), Minas Gerais foi o primeiro Estado brasileiro a conceder esse tipo de incentivo para investimentos no campo do saneamento ambiental.

Assim, visando buscar novas fontes de recursos financeiros estaduais e melhorar a qualidade de vida dos moradores, constata-se, após a promulgação da Lei, que é crescente o número de prefeituras mineiras que se habilitam aos incentivos governamentais que dão suporte à implantação de projetos no campo do saneamento ambiental, especificamente ao tratamento do esgoto e ao tratamento e destinação final dos resíduos sólidos domésticos. No final de 2000, por exemplo, eram 28 municípios atendidos; no início de 2003, 43; no final do mesmo ano, 59 e, no segundo trimestre de 2004, havia 71 municípios habilitados no ICMS Ecológico de Minas Gerais (FEAM, 2002, 2003, 2004 e 2005), sendo que 53 deles possuíam aterros sanitários e/ou usinas de reciclagem de resíduos e compostagem licenciados para operação.

Ressalta-se, porém, em relação ao total de municípios de Minas Gerais, em número de 853 , que a abrangência do programa de incentivo ambiental é ainda extremamente pequena, correspondendo, até maio de 2005, a apenas $8,3 \%$ deles. No que se refere especifi- camente aos projetos de disposição e tratamento de RSU, o ICMS Ecológico atende apenas a $6,7 \%$ dos municípios de Minas Gerais.

Apesar de existirem iniciativas promissoras, como o ICMS Ecológico de Minas Gerais, que buscam amenizar os problemas sanitários e ambientais ligados aos RSU, Jucá (2003) afirma ser grande o número de unidades de reciclagem e compostagem e de disposição final de resíduos sólidos domésticos com deficiências técnicas, operacionais e funcionais.

Diante disso, esta pesquisa buscou avaliar o desempenho operacional qualitativo e analisar os ganhos ambientais advindos da implantação da Lei Robin Hood de Minas Gerais, no que se refere à destinação final e aos sistemas de reciclagem e compostagem de RSU implantados em municípios habilitados no ICMS Ecológico mineiro.

Constituem objetivos principais:

- Verificação dos aspectos de ordem ambiental em aterros sanitários e usinas de compostagem e reciclagem de materiais;

- Avaliação das condições de projeto, implantação, operação e gerenciamento operacional de usinas de reciclagem e compostagem e de aterros sanitários que têm apoio do ICMS Ecológico.

\section{A DISPOSICÃO E O TRATAMENTO DOS RESIDUOS SOLIDOS DOMÉSTICOS NO BRASIL E EM MINAS GERAIS}

Para Jucá (2003), houve, nos últimos anos, melhora significativa nos cuidados com tratamento e destinação final de RSU no Brasil. Como conseqüência dessa evolução, nota-se redução da quantidade de resíduos acumulados em lixões e aumento da quantidade disposta em aterros controlados e sanitários, além de se verificar pequeno crescimento na separação de materiais constituintes dos RSU, visando à reciclagem e compostagem.

Em Minas Gerais, tomando-se como referência a produção de resíduos sólidos domésticos de 0,5 a $0,7 \mathrm{Kg} / \mathrm{ha}$ bitante.dia, observa-se que há produção diária mínima de aproximadamente 9.000 toneladas desse tipo de resíduo, levando em consideração a população atual do Estado, que é de 7.891.494 ha- bitantes, segundo dados populacionais do censo do IBGE de 2000.

Segundo o Jornal da Fundação Estadual do Meio Ambiente (2005), os aterros sanitários e as usinas de reciclagem de resíduos sólidos, em Minas Gerais, atendem 4,4 milhões de pessoas, o equivalente a $30 \%$ da população urbana. Em dezembro de 2002, a população atendida por esses tipos de tratamento e destinação final de resíduos domésticos atingia 2,6 milhões de mineiros. Em 2002, tais sistemas beneficiavam $17,5 \%$ da população; em 2003, 19,9\%; em 2004, 27,4\% (FEAM, 2006).

Segundo o órgão ambiental estadual, apenas 13 aterros sanitários estão regularmente licenciados no Estado. Desses, dez recebem recursos do ICMS Ecológico, perfazendo uma população atendida de 2.733.220 habitantes, ou seja, pouco mais de $15,0 \%$ da população do Estado. Em relação às usinas de tratamento, reciclagem e compostagem de resíduos sólidos domésticos, caracterizadas como unidades bastante simples, onde se faz a triagem manual dos materiais recicláveis e a compostagem da fração orgânica, estão em operação em Minas Gerais 55 unidades, sendo 45 delas instaladas em municípios mineiros que recebem apoio do ICMS Ecológico, todos com população de até 13.000 habitantes (FEAM, 2005).

A população atendida por essa modalidade de tratamento de resíduos sólidos domésticos abrange 257.887 pessoas e representa aproximadamente $1,5 \%$ do total do Estado. Em relação ao volume produzido em Minas Gerais, essas unidades processam cerca de $1,6 \%$ do total de resíduos domésticos gerados, valor bastante próximo do apresentado por Jucá (2003) para o Brasil.

\section{A OPERACÃO DAS USINAS DE TRIAGEM E COMPOSTAGEM DE RESÍDUOS SÓLIDOS DOMÉSTICOS E DOS ATERROS SANITÁRIOS}

As usinas de triagem e reciclagem servem para separação dos materiais recicláveis presentes nos RSU. Esses materiais (papéis, metais, plásticos, vidros etc.), em uma segunda etapa, normalmente desenvolvida fora das dependências da usina, são reintroduzidos no processo industrial, permitindo a re- 
ciclagem e/ou transformação em novos produtos. Diante do elevado percentual de matéria orgânica presente nos resíduos sólidos domésticos, também é realizado, nas chamadas usinas de lixo, o processo da compostagem, de forma a produzir um material humificado com características semelhantes às do fertilizante orgânico.

Os materiais não-recicláveis e os resíduos não-orgânicos separados, posteriormente à elaboração do composto, os chamados rejeitos, são dispostos em aterros sanitários ou em aterros controlados, sendo esta última a prática mais adotada.

No Brasil esse sistema de tratamento dos resíduos sólidos domésticos teve, no início dos anos 80, intensa divulgação junto às administraçôes municipais e muitos municípios experimentaram a técnica como solução definitiva para os problemas ambientais e sanitários advindos da crescente produção de RSU. Porém, segundo Ulbanere (1996), a dinâmica do preço dos recicláveis e a própria qualidade dos materiais oriundos das usinas de reciclagem colocaram dúvidas na propalada eficiência econômica e operacional da atividade.

A respeito da rentabilidade econômica das usinas de triagem e compostagem, Jardim e Wells (1995) e D'Almeida e Vilhena (2000) afirmam que dificilmente a venda dos recicláveis cobre as despesas operacionais e os investimentos financeiros dessas unidades, porém, segundo os próprios autores, os lucros ambientais obtidos e a redução do volume de resíduo a ser aterrado devem ser avaliados positivamente quando se adota esse tipo de alternativa de tratamento.

Sob o aspecto gerencial, Ulbanere (1996) informa que, geralmente, as usinas brasileiras de tratamento de resíduos sólidos operam com ausência de métodos e técnicas de controle operacional e financeiro. Galvão Junior (1994), após estudar 56 usinas de tratamento e reciclagem de RSU no Brasil, afirma que tal dispositivo deve apenas ser uma etapa intermediária do gerenciamento integrado dos resíduos sólidos em um município. Para o autor, a falta de qualidade dos produtos, com presença de impurezas nos materiais recicláveis, contaminação e presença de fragmentos de vidros e plásticos no composto e o elevado percentual de rejeitos gerados, que fica na faixa na faixa de $30 \%$, segundo Jardim e Wells (1995), são fatores para o descrédito desse tipo de sistema de tratamento de RSU.

Apesar desses problemas, segundo D'Almeida e Vilhena (2000), uma usina de triagem e compostagem, quando bem operada, permite diminuição de $50 \%$, em média, do volume de resíduos sólidos que seria destinado aos aterros, permitindo, com isso, redução de custos dos serviços e do aumento da vida útil dos aterros sanitários ou controlados existentes.

$\mathrm{O}$ aterro sanitário, segundo a norma ABNT NBR 8419/1984, é "uma técnica de disposição de resíduos sólidos urbanos no solo sem causar danos à saúde pública e à sua segurança, minimizando os impactos ambientais, método este que utiliza princípios de engenharia para confinar os resíduos sólidos à menor área possível e reduzi-los ao menor volume permissível, cobrindo-os com uma camada de terra na conclusão de cada jornada de trabalho, ou a intervalos menores, se for necessário".

Para a apresentação de projeto de aterro sanitário, a referida norma técnica da ABNT deve ser plenamente atendida, contemplando, além dos dados populacionais e estimativas de crescimento, as características do RSU produzidos, os componentes operacionais e os aspectos geoambientais do meio físico para escolha de uma área adequada de implantação. Os componentes principais do projeto devem contemplar: drenagem e impermeabilização da base, drenagem e tratamento de líquidos percolados, cobertura diária e final dos resíduos, drenagem e tratamento (queima e/ou uso) do biogás, drenagem de águas pluviais e monitoramento ambiental, geotécnico e operacional.

Os aterros sanitários são obras peculiares da engenharia civil, tendo em vista que a sua vida útil coincide com o tempo da própria execução, ao contrário de outros empreendimentos e obras em que se estabelece uma determinada vida útil após a construção. Porém, como em qualquer obra de engenharia, os trabalhos de execução do aterro sanitário devem observar o planejamento e a operação, definidos no projeto, sob pena de inviabilização técnica e ambiental do empreendimento.

Em alguns casos, por não se levarem em conta os aspectos operacionais e técnicos, é comum verificar aterros sanitários operados como verdadeiros lixôes, colocando em risco a salubridade do ambiente, fazendo com que os investimentos do projeto técnico se caracterizem como dinheiro perdido.

\section{METODOLOGIA DA PESQUISA}

Para a condução da presente pesquisa foram inicialmente levantados todos os processos de licenciamento ambiental das usinas de triagem e compostagem de RSU e dos aterros sanitários com apoio financeiro definido pela Lei do ICMS Ecológico e arquivados na FEAM - MG, até dezembro de 2003. Estabeleceu-se que $50 \%$ das unidades de tratamento e de disposição de resíduos fossem estudadas e que a amostra de análise fosse constituída de pelo menos $40 \%$ das usinas de reciclagem e compostagem de municípios de três faixas populacionais: 1) até cinco mil habitantes, 2) de cinco mil a 10 mil habitantes, e 3) superior a $10 \mathrm{mil}$ habitantes. Por Minas Gerais ser um Estado de extensa dimensão territorial, considerou-se que tal procedimento oferecia amostragem significativa dos municípios que tinham, à época, esse tipo de incentivo à gestão dos resíduos sólidos urbanos.

Posteriormente, foram selecionados as unidades de reciclagem de resíduos domésticos e os aterros sanitários, dando-se principal atenção a municípios localizados na região centro-sul do Estado, onde se concentra a maioria dos municípios que recebem recursos do ICMS Ecológico. A seguir, foi feita uma avaliação das condições de projeto, implantação, operação, desempenho ambiental e do gerenciamento operacional das unidades selecionadas para estudo. Para avaliar como um município que teve corte nos incentivos da Lei do ICMS Ecológico opera os sistemas de tratamento e de disposição final de resíduos sólidos domésticos implantados, definiu-se que o estudo também fosse estendido para o único caso registrado com essa particularidade, até a época de desenvolvimento da pesquisa.

Para as unidades de triagem dos recicláveis e compostagem, a análise seguiu o roteiro de avaliação desenvolvido pela Companhia de Tecnologia de Saneamento Ambiental do Estado de São Paulo - CETESB (CETESB, 2003), que determina o Índice de Qualidade da Unidade de Compostagem (IQC). 
Tal roteiro, na forma de um checklist, aborda 40 parâmetros de verificação pontuados de acordo com uma escala de valores, envolvendo as características do local do empreendimento, a infraestrutura implantada e as condições operacionais da unidade de triagem e compostagem de resíduos sólidos domésticos. De acordo com a pontuação obtida pela verificação "in loco", as unidades avaliadas podem ser categorizadas em inadequadas, controladas e adequadas.

No caso dos aterros sanitários, adotou-se instrumento semelhante, com 41 parâmetros, desenvolvido e aplicado anualmente no Estado de São Paulo pela CETESB, desde 1997. Essa avaliação, de maneira análoga à apresentada anteriormente, possibilita o cálculo do Índice de Qualidade de Aterros de Resíduos (IQR), classificando o aterro sanitário, de acordo com a pontuação obtida, nas situações de adequado, controlado e inadequado.

Por fim, a classificação obtida pelo IQC e pelo IQR, associada a entrevistas com os encarregados das unidades analisadas e observações complementares "in loco", possibilitaram a avaliação da eficácia operacional e ambiental dos sistemas de tratamento e de disposição de RSU de municípios que possuem apoio do ICMS Ecológico e, por assim dizer, da própria eficácia da Lei Robin Hood de Minas Gerais, no aspecto saneamento ambiental.

\section{RESULTADOS E DISCUSSÃO}

Até o segundo semestre de 2005, a população atendida pelos incentivos do ICMS Ecológico para reciclagem e compostagem de RSU e aterros sanitários estava próxima de três milhôes de habitantes (16\% do total da população de Minas Gerais) e já havia sido repassado, desde o início de sua vigência, perto de R\$ 25 milhões. Mais de $50 \%$ desse montante (aproximadamente $\mathrm{R} \$ 13.263 .307,00)$ foram aplicados em aterros sanitários dos municípios de Betim, Belo Horizonte, Extrema, Paracatu, Três Coraçôes, Ipatinga, Santana do Paraíso, Lima Duarte, Arcos e Visconde do Rio Branco (FEAM, 2005). Constata-se, porém, que, para os aterros sanitários, a quase totalidade dos recursos do ICMS Ecológico foi destinada aos municípios de Betim e Belo Horizonte. Betim teve repasses de
R\$ 6.408.725,27 e Belo Horizonte recebeu R\$ 5.914.941,87 (FEAM, 2005).

Levando-se em consideração os 53 municípios mineiros que receberam os benefícios do ICMS Ecológico, até o segundo semestre de 2004, por operar usinas de triagem e compostagem de resíduos e ou aterros sanitários, nota-se que, em $62 \%$ deles, os sistemas implantados atendiam à totalidade da população urbana do município.

Tomando-se como base o porte das cidades, as usinas de triagem e compostagem atendem unicamente a cidades de pequeno porte, sendo que 25 delas, ou seja, $52 \%$ têm população menor do que cinco mil habitantes; 18 cidades $(37,5 \%)$ têm uma população entre cinco e 10 mil habitantes e apenas quatro cidades $(8,3 \%)$ têm população maior que 10 mil habitantes, porém não ultrapassando 15.000 habitantes.

Por outro lado, no que se refere aos sistemas de disposição de resíduos domésticos na forma de aterros sanitários, constata-se que a população das cidades atendidas é variável e que o ICMS Ecológico está sendo concedido a municípios bastante populosos e para alguns considerados "ricos". $\mathrm{Na}$ faixa dos municípios com mais de 200 mil habitantes estão Ipatinga, na Zona Metalúrgica, e Betim, na região metropolitana de Belo Horizonte. Os de porte médio, com população em torno dos 50 mil habitantes, são Paracatu, no noroeste mineiro, e Três Coraçôes, no sul do Estado. Entre os de 10 e 20 mil habitantes estão Extrema, Santana do Paraíso, Arcos e Visconde do Rio Branco. O município de Belo Horizonte, com um aterro sanitário que atende a mais de dois milhôes de habitantes, pode ser considerado uma exceção neste quadro.

Geograficamente constata-se que a maioria dos municípios que detêm apoio do ICMS Ecológico, principalmente para a modalidade tratamento de resíduos domésticos, se localiza na porção centro-sul de Minas Gerais. Entende-se como natural essa distribuição, principalmente tendo em vista ser a região metropolitana de Belo Horizonte, o Sul de Minas e o próprio Estado de São Paulo, os maiores centros consumidores dos materiais recicláveis produzidos nas usinas de triagem de resíduos sólidos domésticos.

\section{Desempenho operacional e ambiental das unidades de tratamento de resíduos sólidos domésticos}

Ao todo foram estudadas 20 unidades de triagem e compostagem de resíduos domésticos das que receberam recursos do ICMS Ecológico até dezembro de 2003. Como estabelecido metodologicamente, a seleção das usinas de reciclagem e compostagem pesquisadas baseou-se na lista de repasse de recursos do ICMS Ecológico até aquele período, na localização geográfica do município e na populaçãa da cidade atendida pelo serviço.

Assim sendo, fizeram parte da pesquisa oito usinas de reciclagem de resíduos de municípios de até cinco mil habitantes, equivalentes a $21 \%$ do total das unidades em operação à época e a $44 \%$ dos municípios desse porte; sete usinas de municípios com população atendida na faixa de cinco a 10 mil habitantes, correspondendo a $18,5 \%$ do total dos que tinham apoio do ICMS Ecológico e a $42 \%$ dos municípios deste porte, e duas unidades de reciclagem de municípios com atendimento superior a 10 mil habitantes, correspondendo a $13 \%$ do total de cidades contempladas e a $40 \%$ das cidades do respectivo porte que recebem os incentivos da Lei n. ${ }^{\circ} 13.803 / 2000$. Além dessas unidades, também fez parte do presente estudo a análise de um aterro sanitário e uma usina de triagem e compostagem de município penalizado com a perda dos incentivos oriundos do ICMS Ecológico, devido ao não-atendimento das orientações técnicas e exigências estabelecidas pelo órgão ambiental do Estado.

A aplicação da metodologia de análise para definir a classificação do índice de qualidade (IQC), que reflete as condiçôes operacionais e ambientais das unidades de triagem e compostagem, mostrou que mais da metade das unidades estudadas (12 em 20 casos) apresentava valores de IQC que revelam condiçôes adequadas de funcionamento. Mas, por outro lado, constatou-se que nenhuma delas obteve a pontuação máxima possível do índice da CETESB e que sete delas apenas apresentavam condições aceitáveis de operação e desempenho.

$\mathrm{O}$ estudo revelou ainda que essas unidades apresentavam deficiências nas instalaçôes, além de problemas relacio- 
nados aos aspectos operacionais. $\mathrm{Na}$ Tabela 1 é apresentada a situação para o item do IQC de cada uma das usinas de triagem e compostagem de resíduos estudadas bem como a classificação final, segundo as condições de desempenho estabelecidas pela CETESB.

Observa-se que, mesmo apresentando deficiências, as unidades de reciclagem de resíduos sólidos domésticos que têm incentivos do ICMS Ecológico não são consideradas problemáticas, como alguns autores verificaram em suas pesquisas (Galvão Junior, 1994 e Ulbanere, 1996), pois se constatou que as mesmas desempenham bem o papel para o qual foram projetadas, que é permitir a reciclagem de materiais presentes em RSU com qualidade ambiental e operacional.

Nas usinas de triagem classificadas em condições aceitáveis, percebe-se que todos os itens de avaliação apresentam valores que contribuíram para a queda global do IQC, quando comparados com as das que obtiveram maiores pontuações para o índice. Entretanto, nas visitas às usinas, ficou patente que a maioria delas tem problemas geralmente ligados às questôes gerenciais $\mathrm{e}$ operacionais. Pode-se também dizer que o desempenho operacional e ambiental da usina é bastante dependente do trabalho desenvolvido, exigência e envolvimento nas tarefas pelo encarregado geral da unidade.

Levando em consideração a documentação arquivada no órgão ambiental do Estado, constatou-se pelas análises documentais que a FEAM-MG acompanha e avalia sistemática e periodicamente esses sistemas de triagem e compostagem de resíduos domésticos e isso parece ser fator para que as unidades que recebem o incentivo do ICMS Ecológico apresentem desempenho operacional e ambiental satisfatório.

As visitas periódicas dos técnicos do órgão ambiental, às unidades estudadas, como registrado na documentação analisada, parecem também determinar uma tendência da evolução da qualidade operacional e ambiental das usinas de tratamento de RSU, pois, além de contribuir para uma melhoria contínua dos empreendimentos, a ação fiscalizadora, e, ao mesmo tempo considerada pró-ativa, inibe práticas inadequadas e improvisaçôes operacionais. Adicionalmente, visando melhorar o desempenho da reciclagem e da compostagem nas usinas, o órgão ambiental do Estado em parceria com a Fundação Centro Tecnológico de Minas Gerais - CETEC vinha desenvolvendo, à época de desenvolvimento do presente trabalho, o projeto Suporte ao Gerenciamento Integrado dos RSU em Municipios com Usinas de Triagem e Compostagem, oportunizando aos técnicos das usinas melhor capacitação para a operação e desenvolvimento de atividades nas unidades com apoio do ICMS Ecológico.

Do grupo estudado, constatou-se apenas uma usina de reciclagem caracterizada como em condições inaceitáveis de operação pelo instrumento da CETESB, obtendo valor do IQC de 5,2. Trata-se da usina de Carmo do Rio Claro, que foi único município a perder os incentivos estabelecidos pela Lei, por não seguir as orientações técnicas e as exigências da FEAM. É interessante ressaltar que o referido município também recebia incentivos do ICMS Ecológico para aterro sanitário e, pelos mesmos motivos, deixou de recebê-los. $\mathrm{O}$ caso mostra que os benefícios advindos da Lei 13.803/2000 são concretos, pois, após o seu corte, contatou-se visível retrocesso na gestão de RSU pelo município que detinha o incentivo fiscal-ambiental.

Um resumo das principais características de cada unidade de triagem e compostagem de resíduos estudada pode ser visto na Tabela 2 .

Considera-se importante salientar, porém, que as usinas de reciclagem de resíduos financiadas pelo ICMS Ecológico de Minas Gerais são bastante rudimentares sob o ponto de vista de desenvolvimento tecnológico e uma solução típica de países em desenvolvimento, devido, principalmente, às condições insalubres e degradantes de trabalho dos operadores que fazem a catação e a separação dos recicláveis. Nesse aspecto, entende-se que o sistema de triagem de resíduos precisa evoluir, apesar do órgão ambiental exigir para os operadores da usina que trabalham na separação dos recicláveis do uso de equipamentos de proteção individual e de obrigatoriamente estarem em dia com a vacinação e imunização contra doenças infecciosas.

\section{O composto produzido nas usinas de reciclagem e compostagem de resíduos}

Para o composto orgânico produzido nas usinas, com base na Lei do ICMS Ecológico, e para fins de manutenção dos repasses da parcela dos recursos, são exigidas análises semestrais dos seguintes parâmetros: densidade, $\mathrm{pH}$, sólidos voláteis, nitrogênio $(\mathrm{N})$, fósforo $(\mathrm{P})$, potássio $(\mathrm{K})$ e carbono total (C). Além desse monitoramento, são exigidas análises anuais bacteriológicas (coliformes e estreptococos) e de metais pesados ( $\mathrm{Hg}, \mathrm{Cu}, \mathrm{Zn}, \mathrm{Cr}, \mathrm{Pb}, \mathrm{Ni}$ e Cd). Os relatórios dessas análises devem ser encaminhados à FEAM e os valores obtidos para cada um dos parâmetros analisados devem ser acompanhados para fins de orientação ou restrição de uso do material oriundo dos pátios de compostagem das usinas.

Quando o composto produzido nas usinas é contaminado com metais pesados, a FEAM proíbe o uso do material na agricultura, orientando, porém, a utilização alternativa em canteiros de praças e jardins da cidade. Há, no entanto, poucos casos em que as análises químicas do composto mostram que o produto é indicado para produção de alimentos e de hortaliças. Nas usinas onde o composto produzido não está contaminado, é comum os funcionários terem hortas e pomares com solo tratado com o "adubo" produzido. Tal fato foi verificado nas unidades de tratamento de RSU de Guiricema e de Guarani, sendo que nesta também se produzem mudas de frutíferas para fábricas de sucos da região.

Quando o composto orgânico é comercializado, como acontece nas usinas de Coimbra e de Guiricema, o preço de venda varia entre $R \$ 20,00$ e $\mathrm{R} \$ 25,00$ a tonelada. No entanto, em outro caso, como na usina de Dionísio, o composto estava estocado e vinha sendo doado para uso "apenas em adubação" de plantas frutíferas e cafezais. Apesar de apresentar contaminação por metais pesados, nem a Prefeitura e tampouco o órgão ambiental do Estado faziam o controle do uso do material após a saída da unidade de compostagem. Neste caso, por falta de acompanhamento das autoridades é possível que, mesmo contaminado e tendo seu uso restrito, o produto poderia estar sendo aplicado indevidamente no solo.

Cabe ressaltar, conforme registram D'Almeida e Vilhena (2000) e Monteiro (2001), que a legislação brasileira não define concentrações máximas para metais pesados no composto orgânico oriundo de usinas de compostagem. A Portaria do Ministério da Agricultura (MA 84, de 29/3/82) estabelece apenas 
Tabela I - Valores atribuídos a cada item de análise do IQC e classificação final para as unidades de triagem e compostagem de resíduos sólidos domésticos com incentivos do ICMS Ecológico de Minas Gerais

\begin{tabular}{cccccc}
\hline Município & $\begin{array}{c}\text { Características } \\
\text { ambientais } \\
\text { da área }\end{array}$ & $\begin{array}{c}\text { Infra- } \\
\text { estrutura da } \\
\text { usina }\end{array}$ & $\begin{array}{c}\text { Condiçóes } \\
\text { operacionais } \\
\text { da usina }\end{array}$ & $\begin{array}{c}\text { Valor } \\
\text { do } \\
\text { IQC }\end{array}$ & $\begin{array}{c}\text { Condiçóes } \\
\text { da usina de } \\
\text { triagem }\end{array}$ \\
\hline Guarani & 19 & 55 & 54 & 9,1 & Adequada \\
Cel. Xavier Chaves & 19 & 53 & 55 & 9,0 & Adequada \\
Carmo da Cachoeira & 20 & 53 & 53 & 9,0 & Adequada \\
Candeias & 20 & 53 & 52 & 8,9 & Adequada \\
Jacuí & 18 & 51 & 53 & 8,7 & Adequada \\
Itaú de Minas & 19 & 52 & 48 & 8,5 & Adequada \\
Dionísio & 19 & 51 & 48 & 8,4 & Adequada \\
Alterosa & 16 & 49 & 50 & 8,2 & Adequada \\
S. Joaquim de Bicas & 16 & 53 & 45 & 8,1 & Adequada \\
Guiricema & 19 & 46 & 49 & 8,1 & Adequada \\
S. José do Goiabal & 19 & 46 & 48 & 8,1 & Adequada \\
S. D. do Prata & 14 & 51 & 49 & 8,1 & Adequada \\
Eugenópolis & 15 & 48 & 41 & 7,9 & Aceitável \\
Maripá & 15 & 48 & 44 & 7,6 & Aceitável \\
Entre Rios de Minas & 15 & 42 & 48 & 7,5 & Aceitável \\
Carmo da Mata & 17 & 46 & 45 & 7,5 & Aceitável \\
Iguatama & 19 & 48 & 34 & 7,2 & Aceitável \\
Coimbra & 11 & 42 & 41 & 6,7 & Aceitável \\
Goiana & 14 & 44 & 36 & 6,7 & Aceitável \\
Carmo do Rio Claro & 12 & 49 & 13 & 5,2 & Inadequada \\
\hline
\end{tabular}

Observação: A pontuação máxima possível para as características do local de instalação da usina de reciclagem de resíduos é 20 pontos; para infra-estrutura instalada 65 pontos e para as condições operacionais da usina 55 pontos.

que "no requerimento de registro, o produto (fertilizante) deverá apresentar declaração expressa de ausência de agentes fitotóxicos, agentes patogênicos ao homem, animais e plantas, assim como metais pesados, agentes poluentes, pragas e ervas daninhas". Portanto, como se verifica, não se estabelecem limites toleráveis de sua aplicação no solo, onde as substâncias podem ter efeito cumulativo. Neste caso relatado, constatam-se falhas por conta das autoridades no que se refere no acompanhamento do uso desses materiais quando apresentam elevados níveis de metais pesados.

Por outro lado, como o órgão ambiental estabelece restriçóes de uso e em outros casos permite a venda do composto, ou uso para a aplicação na agricultura, seria necessário que se buscassem, mesmo não havendo exigência legal do Ministério da Agricultura, o registro do material produzido nas usinas de compostagem. Considera-se também a necessidade de avanços na legislação brasileira visando o registro do composto no MA, já que se tem verificado aumento da produção desses materiais em decorrência da implantação de usinas de compostagem de RSU no Brasil.

Do observado nos relatórios das análises químico-bacteriológicas do composto obtido nas usinas visitadas e nos registros da FEAM, verificaram-se situações que merecem atenção: a) raramente os relatórios analíticos da análise do composto produzido apresentam um laudo técnico conclusivo a respeito dos valores obtidos para cada parâmetro; b) nem todos os relatórios informam os métodos utilizados para a condução das análises do composto; c) faltam informações sobre os valores de referência quanto à qualidade do material (mesmo o estabelecido por organismos internacionais, principalmente para os potenciais contaminantes -os metais pesados); d) apesar do órgão ambiental exigir um responsável técnico para a operação das usinas de triagem e compostagem, constatam-se dificuldades por parte das prefeituras e dos próprios técnicos das usinas em entender os resultados das análises químicas do composto.

Esse último tema constitui-se num ponto crítico no que concerne a gestão das usinas e do uso sustentável e comercialização de um dos seus principais produtos (o composto), pois, como relatado, a falta de clareza dos laudos de análise do material e a baixa qualidade do composto pode por em risco o ambiente do solo e o que se produz nele quando se utiliza o produto das usinas que têm apoio do ICMS Ecológico. 
Prado Filho, J. F. \& Sobreira, F. G.

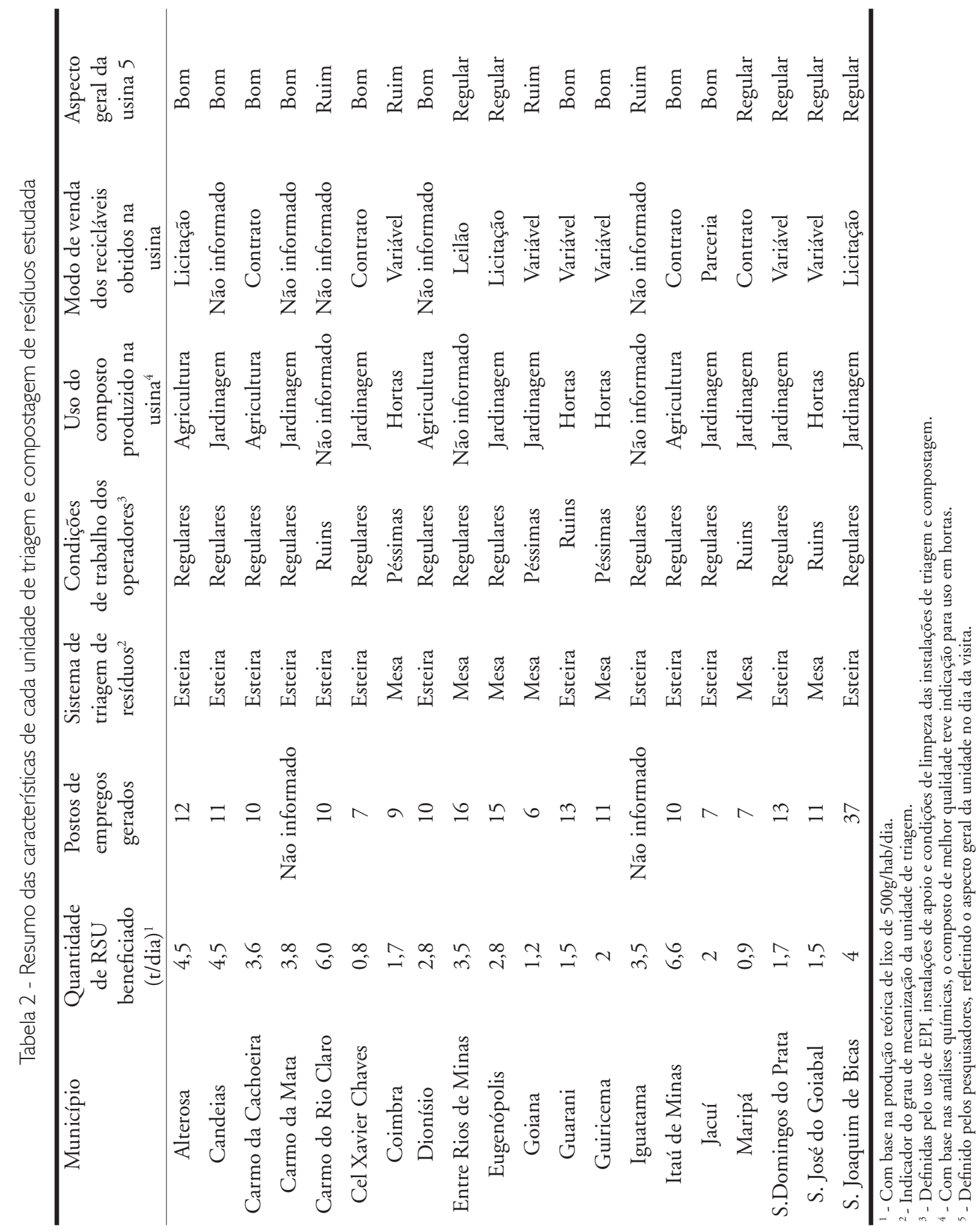


Diante desse quadro, percebe-se que tanto os responsáveis técnicos das usinas, que freqüentemente têm dificuldades de entender os laudos dos resultados da análise do composto e o próprio órgão ambiental, pela falta de esclarecimento e acompanhamento do uso do produto e da fragilidade das normas que envolvem a legalização do uso do composto permitem que se alertem as autoridades sobre as questóes que envolvem a operacionalização das usinas e a aplicação do composto no solo.

Além dessas considerações, verifica-se que a composição do material, principalmente no que se refere à presença de contaminantes, é bastante variável entre as usinas estudadas, o que permite colocar dúvidas sobre a compostagem nas unidades de tratamento de resíduos sólidos domésticos financiadas pelo ICMS Ecológico. Essas variações devem-se principalmente ao fato da coleta seletiva dos resíduos domésticos não estar implantada nas cidades que têm incentivos do ICMS Ecológico e também da forma como se conduz a separação dos materiais nas frentes de triagem das usinas de reciclagem.

\section{A gestão dos materiais recicláveis e rejeitos das usinas financiadas pelo ICMS ecológico}

Constatou-se, em todas as usinas estudadas, que os materiais separados dos RSU têm grande facilidade de venda, principalmente para indústrias do interior do Estado de São Paulo e da região metropolitana de Belo Horizonte. Em alguns casos, a venda é feita por convite ou por meio de leilóes (Tabela 2). Nessas situaçóes, os valores obtidos são mais vantajosos.

Um dos produtos das usinas de reciclagem que apresentam baixa procura pelos intermediários é o vidro, porém, mesmo assim, esse material normalmente não fica estocado por longo tempo. Somente na usina de Coimbra, que se localiza na Zona da Mata mineira, constatou-se dificuldade de venda dos resíduos dessa categoria.

Sobre a administração financeira das usinas, nenhum dos encarregados soube apresentar detalhes contábeis e constatou-se que a própria FEAM exige apenas um relatório trimestral, em formato padrão, de produção de materiais recicláveis, sem dar atenção à contabi- lidade e ao fluxo de caixa das unidades. É fato, porém, como apresenta a literatura, que tais empreendimentos não devem ser vistos como iniciativas com que se buscam lucros financeiros, e sim que visam, pelo menos, diminuir o volume de resíduos destinados aos locais de despejo e com isso reduzir os impactos socioambientais provocados tanto no ambiente urbano como no local de disposição final. Sobre esse aspecto, relata-se o trabalho de Brito et al (2000) que observaram que a venda dos recicláveis e do composto produzido na unidade de reciclagem e compostagem de Coimbra (MG), cobria apenas 64\% dos custos operacionais da usina.

Constatou-se, também, que todas as usinas de triagem e compostagem operavam valas para a disposição final dos rejeitos do processo de separação dos recicláveis e da preparação do composto orgânico. Essas estruturas, que são exigidas no licenciamento ambiental das unidades, normalmente são instaladas em terrenos da própria usina, porém se observou que as mesmas não vinham sendo operadas de maneira a atender aos aspectos de ordem sanitária, geotécnica e ambiental. Trata-se de um problema ambiental que necessita ser urgentemente resolvido.

Nenhuma das valas possuia sistema de impermeabilização da base e poucas tinham drenos para o chorume produzido, como o verificado na unidade de São José do Goiabal. Foi comum encontrar valas com resíduos espalhados e sem compactação e recobrimento, valas construídas e localizadas aleatoriamente e sem critérios técnicos e trincheiras abertas, descobertas e sem isolamento da área. Em algumas usinas, os resíduos não segregados, em épocas de maior produção, estavam sendo lançados diretamente nas valas. Por outro lado, algumas usinas operavam suas valas de maneira bastante peculiar, como nas usinas de Carmo da Cachoeira e de Jacuí, onde se constatou que o material rejeitado era, antes da disposição final, prensado e enfardado, com posterior acomodação orientada no solo, visando utilizar menos espaço e volume na vala sanitária.

Pelas observaçôes "in loco", conclui-se serem as valas de rejeitos das usinas de reciclagem dos RSU geradoras de problemas ambientais ainda sem solução, pois a ausência de técnicas adequadas durante a operação permite a contaminação e a poluição do solo adjacente às suas instalaçôes.

\section{Desempenho operacional e ambiental dos aterros sanitários financiados pela Lei Robin Hood}

Dentre os nove aterros sanitários que recebiam, até o segundo semestre de 2003, os incentivos da Lei, cinco foram estudados. Foram analisados um aterro sanitário de grande porte, da cidade de Betim, dois aterros de médio porte, de Três Coraçóes e Paracatu, e dois de pequeno porte, de Extrema e Carmo do Rio Claro, sendo o desta última cidade o que perdeu, após insistentes orientações do órgão ambiental, os incentivos do ICMS Ecológico.

Após a aplicação do instrumento de análise de aterros sanitários - IQR, constatou-se que dois deles apresentavam condições adequadas de instalação e operação, enquanto os outros dois foram classificados como em condições controladas, principalmente por evidenciar problemas de operação e condução técnica da obra. O único aterro classificado como em condições inadequadas, segundo o IQR, foi o de Carmo do Rio Claro.

Por serem obras peculiares, cada uma delas apresenta características diversas no que se refere aos itens constantes de avaliação do IQR e, por isso, uma comparação item a item constitui tarefa de difícil execução, não fornecendo subsídios para comparações objetivas. Os valores atribuídos aos conjuntos de parâmetros de análise e os valores de IQR de cada unidade estudada estão mostrados na Tabela 3 .

Observou-se que o aterro sanitário que apresentou maior pontuação para a infra-estrutura implantada - 43 de 45 pontos possíveis - e para as condições de operação do empreendimento - 40 de 45 pontos possíveis - foi o de Betim. A pontuação total obtida para o IQR foi de 8,9 dos 10 pontos possíveis, pois o referido aterro apresenta deficiências quanto à localização, estando implantado próximo de núcleos habitacionais, e em relação às condições operacionais, tendo em vista a presença de urubus, recebimento, à época da análise, de resíduos sólidos hospitalares e deficiências no funcionamento do sistema definitivo de drenagem de águas pluviais e na infra-estrutura implantada.

Os aterros sanitários de médio porte estudados foram classificados como em situação controlada e, por isso, merecem cuidados no que se refere 
aos aspectos da infra-estrutura e às condições de operação. Entre todos os aterros sanitários estudados, o de Paracatu foi o único a obter a pontuação máxima para o item características do local de execução da obra - 40 pontos, mas obteve pontuação muito baixa para o item condições operacionais - 21 dos 45 pontos possíveis, e para infra-estrutura - 31 dos 45 pontos possíveis, fatos que influenciaram negativamente no valor do IQR. Na visita ao referido aterro foi possível verificar a ocorrência de resíduos sólidos descobertos, recobrimento inadequado do material, presença de urubus e moscas, descarga de resíduos de serviços de saúde, problemas com os sistemas de drenagem pluvial provisória e definitiva e do sistema de drenagem do chorume, etc. Portanto, mesmo se caracterizando como aterro em condições controladas, verificou-se a necessidade de intervenções técnicas de operação e de melhoria na infra-estrutura.

Apesar do aterro sanitário de Três Coraçôes apresentar um valor de IQR igual a 8,1 constataram-se deficiências no que se refere a todos os itens do índice da CETESB, ou seja: proximidade de corpo d'água, média permeabilidade do solo, péssimas condições do sistema viário interno, inexistência de drenagens de águas pluviais, descumprimento a itens importantes do projeto, ocorrência de resíduos sem recobrimento, intensa presença de urubus e moscas, funcionamento precário das drenagens de águas pluviais. Do visto, apesar do IQR caracterizá-lo como um aterro em condiçōes adequadas, é possível afirmar que, com a adoção de medidas técnicas e operacionais simples, pode-se obter melhor desempenho e, portanto, elevar o valor do IQR, que está na faixa-limite dentre aterro em condiçóes controladas e aterro em condições adequadas.
O aterro sanitário de Extrema é uma unidade de pequeno porte, já que recebe apenas cerca de seis toneladas de resíduos por dia. A unidade apresentava deficiências com relação a todos os itens do IQR, tendo o menor desempenho dentre os aterros estudados, com um índice final de 6,7. Dos itens avaliados, a menor pontuação obtida coube às condições operacionais, atingindo apenas 22 dos 45 pontos possíveis. As deficiências operacionais verificadas foram: presença e recobrimento inadequado dos resíduos, presença de urubus e moscas, descarga de resíduos de serviços de saúde, descarga de resíduos industriais, defeitos no funcionamento dos sistemas de drenagem de águas pluviais definitivas e provisórias, drenagem irregular do chorume, insuficiência de manutenção de acessos internos e vigilância ruim. Das constatações in loco, considerou-se que o aterro de Extrema deve ser operado com maior atenção e com cuidados técnicos rígidos.

Da análise do aterro sanitário de Carmo do Rio Claro, constatou-se o esperado, ou seja, um depósito de resíduos domésticos em condições inadequadas de operação e desempenho ambiental, obtendo 5,3 como valor do IQR. Dos itens que compõem esse índice, o que se mostrou mais problemático foi aquele que envolve as condiçōes técnico-operacionais do aterro, tendo apenas 19 dos 45 pontos possíveis, porém constatou-se que os outros itens que compóem o índice também tiveram pontuação baixa (Tabela 3). Isso se deveu principalmente ao fato de que a administração municipal local deu pouca atenção às orientações técnicas e aos alertas do órgão ambiental para com a operação irregular e deficiente do aterro sanitário. Diante disso e, com base no estabelecido pela Lei do ICMS
Ecológico, o município teve cortado os repasses das parcelas referentes ao incentivo ambiental.

Do verificado pela pesquisa, considera-se que o incentivo da Lei Robin Hood para investimentos em aterros sanitários é positivo, tendo em vista que as unidades que obtiveram os maiores valores de IQR são aquelas que mantêm tal apoio. Isso não se deve somente às verbas repassadas aos municípios para operação dos aterros, mas também às outras exigências ambientais, como encerramento obrigatório dos lixões, a implantação de programa de coleta seletiva, etc., definidos na fase de licenciamento dos empreendimentos e nas ações pró-ativas e fiscalizadoras do órgão ambiental estadual.

Apesar disso, constata-se que essas açōes ainda não são completamente eficazes para a solução definitiva das questôes que envolvem RSU, tendo em vista que até mesmo os sistemas que possuem o referido incentivo apresentam problemas operacionais e técnicos, resultando em impactos ambientais importantes.

\section{CONCLUSÕES}

$\mathrm{O}$ estudo permitiu constatar que a Lei Estadual n. ${ }^{\circ}$ 13.803/2000 de Minas Gerais traz benefícios no campo do saneamento ambiental, embora seja ainda reduzido o número de municípios mineiros contemplados pelo incentivo que ela estabelece.

A regulamentação estabelecida pelo Sistema de Meio Ambiente de Minas Gerais que exige dos municípios pleiteantes ao ICMS Ecológico, nas fases de licenciamento do aterro ou usina de reciclagem de resíduos a apresentação de projetos para o encerramento de lixóes e/ou vazadouros irregulares e, adicionalmente, implementar sistemas de gestão integrada dos resíduos sólidos,

Tabela 3 - Valores atribuídos a cada item de análise do IQR e classificação final para aterros sanitários com incentivos do ICMS Ecológico de Minas Gerais

\begin{tabular}{cccccc}
\hline Município & $\begin{array}{c}\text { Características } \\
\text { ambientais } \\
\text { da área }\end{array}$ & $\begin{array}{c}\text { Infra-estrutura } \\
\text { do aterro }\end{array}$ & $\begin{array}{c}\text { Condiçóes } \\
\text { operacionais } \\
\text { do aterro }\end{array}$ & $\begin{array}{c}\text { Valor do } \\
\text { IQR }\end{array}$ & $\begin{array}{c}\text { Classificação } \\
\text { do aterro }\end{array}$ \\
\hline Betim & 35 & 43 & 40 & 8,9 & Adequado \\
Três Corações & 33 & 38 & 35 & 8,1 & Adequado \\
Paracatu & 40 & 31 & 21 & 7,1 & Controlado \\
Extrema & 32 & 33 & 22 & 6,7 & Controlado \\
Carmo do Rio Claro & 27 & 23 & 19 & 5,3 & Inadequado \\
\hline
\end{tabular}


tem contribuído de forma positiva para a melhoria da qualidade ambiental em seus domínios. Ademais, a fiscalização da agência governamental nesses empreendimentos é fator considerado importante para a melhoria contínua desses sistemas. Considera-se também que o bom desempenho nos índices IQC e IQR das unidades avaliadas é conseqüência do processo de licenciamento das unidades e resultado do envolvimento dos técnicos que operam tais sistemas.

Com o estudo, verificou-se que, em todas as usinas de triagem e compostagem, os materiais recicláveis têm grande facilidade de venda e que o composto orgânico produzido apresentam concentrações variáveis de metais pesados entre as unidades analisadas, o que põe dúvidas sobre o processo de compostagem desenvolvido nas usinas financiadas pelo ICMS Ecológico e, principalmente, no posterior uso do produto no solo.

Por outro lado, as formas inadequadas de construção e operação das valas de rejeitos das usinas de reciclagem também são considerados problemas importantes e, portanto, tais dispositivos deveriam receber maior atenção por parte da FEAMMG, das prefeituras e dos responsáveis técnicos das usinas de beneficiamento e reciclagem de resíduos sólidos.

Com respeito aos aterros sanitários, verifica-se situação diversa, uma vez que, por serem obras peculiares e terem vida útil coincidindo com o próprio tempo de execução, exigem que as orientações do projeto e operação sejam rigorosamente seguidas, sob pena de torná-los problemáticos do ponto de vista ambiental. Assim, verificou-se que tais sistemas, mesmo sendo relativamente bem avaliados pelo IQR, apresentam problemas operacionais e técnicos, exigindo, principalmente naqueles de pequeno e médio portes, maior atenção por parte dos responsáveis pela sua operação.

Apesar das deficiências constatadas, é possível afirmar que o apoio do ICMS Ecológico, na modalidade tratamento e disposição dos resíduos sólidos domésticos, atende satisfatoriamente aos objetivos propostos, atestando o acerto, por parte de Minas Gerais, na implementação de um sistema de gestão ambiental de RSU calcado no chamado princípio do tipo protetor-recebedor. Torna-se necessário, porém, abranger número maior de municípios no pro- grama e a implementação de sistemas que visem à melhoria contínua da operação dos aterros sanitários e das usinas de tratamento e reciclagem que têm financiamento do ICMS Ecológico.

Com referência aos instrumentos utilizados para o cálculo do IQC e IQR algumas considerações se fazem necessárias. Por ser cada um dos itens dos referidos índices pontuados qualitativamente e por representarem características e situaçôes observadas no momento da avaliação da unidade de saneamento, considera-se que o uso de tais ferramentas pode trazer distorçôes na pontuação final de cada unidade avaliada. Esta afirmação se baseia no modo de aplicação do instrumento por diferentes profissionais e o próprio rigor técnico de quem executa a tarefa. Tais situaçôes podem resultar em distorção no resultado final do IQC e IQR. Adicionalmente, outro aspecto que mostra fragilidade no instrumento é que o mesmo se vale da avaliação expedita e momentânea no empreendimento, já que o mesmo não se apóia em ensaios de campo ou laboratoriais ou outros tipos de estudos, representando apenas as condiçôes no momento da inspeção.

Assim, mesmo apresentando tais deficiências e na atual ausência de outros instrumentos que tenham a finalidade de uma avaliação integrada dos fatores que se relacionam com aterros e usinas de tratamento e compostagem de resíduos, entende-se que a metodologia utilizada permite uma uniformização de procedimentos e serve para avaliar qualitativamente e a evolução do desempenho técnico-operacional e ambiental de aterros e/ou usinas de compostagem. Considera-se, inclusive, como fator importante para uso dessa ferramenta de análise, ser uma metodologia de fácil aplicação e de baixo custo.

\section{REFERÊNCIAS}

ASSOCIAÇÃO BRASILEIRA DE NORMAS TÉCNICAS -ABNT. Apresentação de projetos de aterros sanitários de resíduos sólidos urbanos - Procedimento. NBR-8419/84. São Paulo, 13p. 1984.

BRITO, K.G.Q.; PEREIRA NETO, J. T.; CEBALLOS, B.S.O. Estimativa dos ganhos socioeconômicos com a reciclagem e compostagem do lixo de Coimbra - MG: estudo de caso. In: XXVII CONGRESSO INTERAMERICANO DE ENGENHARIA SANITÁRIA E AMBIENTAL. Porto Alegre, 2000.

COMPANHIA DE TECNOLOGIA DE SANEAMENTO AMBIENTAL DO ESTADO
DE SÃO PAULO - CETESB. Inventário Estadual de Resíduos Sólidos Domiciliares-Relatório Sintese. São Paulo: CETESB, 42 p. 2003.

D'ALMEIDA, M.L.O.; VILHENA, A. Lixo $M u$ nicipal: manual de gerenciamento integrado. $2^{\circ} \mathrm{ed}$. São Paulo: IPT/CEMPRE, 370p. 2000.

FUNDAÇÃO ESTADUAL DO MEIO AMBIENTE - FEAM. ICMS Ecológico. Revista FEAM. Belo Horizonte, p19 (dez). 1998.

FUNDACÃO ESTADUAL DO MEIO AMBIENTE - FEAM. Repasse de recursos do ICMS Ecológico: Sub-critério Saneamento Ambiental. <www.feam.br>- Acesso em: 09 fev.2002.

FUNDAÇÃO ESTADUAL DO MEIO AMBIENTE - FEAM. Municípios habilitados no ICMS Ecológico (modalidade saneamento) até o $3^{\circ}$ trimestre de 2003. <www.feam.br $>-$ Acesso em: em 02 abr. 2004.

FUNDAÇÃO ESTADUAL DO MEIO AMBIENTE - FEAM. Municipios habilitados no ICMS Ecológico (modalidade saneamento) até o $2^{\circ}$ trimestre de 2004. <www.feam.br $>$ - Acesso em: em 15 mai. 2005.

FUNDAÇÃO ESTADUAL DO MEIO AMBIENTE - FEAM. Percentuais de evolução de disposição, tratamento de lixo e esgoto em Minas Gerais.<www.feam.br>-Acesso em: 17 fev. 2006.

GALVÃO JUNIOR, A.C. Aspectos operacionai relacionados com usinas de reciclagem e compostagem de resíduos sólidos domiciliares no Brasil. Dissertação (mestrado) - EESC - Universidade de São Paulo, São Carlos, 113f. 1994.

JARDIM, N.S.; WELLS, C. Lixo Municipal: manual de gerenciamento integrado. São Paulo IPT/CEMPRE, 278 p. 1995.

Jornal da FEAM, Belo Horizonte, Ano III, n.23, p.2, agosto de 2005 .

JUCÁ, J. F. T. Disposição final dos resíduos sólidos urbanos no Brasil. In: V CONGRESSO BRASILEIRO DE GEOTECNIA AMBIENTAL. Anais... Porto Alegre: REGEO, p. 443-470. 2003

MONTEIRO, J.H.P. et al. Manual de Gerenciamento Integrado de Resíduos Sólidos. Coordenação técnica Victor Zular Zveibil. Rio de Janeiro: IBAM, 200p. 2001.

ULBANERE, R.C. Análise ambiental de usinas de reciclagem de resíduos sólidos. Revista Eng. Ciênc. Aplic., São Paulo, vol.3. p.57-74, 1996.

Endereço para correspondência:

José Francisco do Prado Filho Universidade Federal de Ouro

Preto

Departamento de Engenharia de

Produção

Campus Universitário

35400-000 Ouro Preto - MG -

Brasil

Tel. (3I)3559-1563

E-mail: jfprado@depro.em.ufop.br 